\title{
Analisis Resiko Sistem Informasi Penjualan Berbasis ISO 31000: Study Kasus PT XYZ
}

\author{
Endang Saputra, Christ Rudianto, Penidas Fiodinggo Tanaem
}

Program Studi Sistem Informasi, Fakultas Teknologi Informasi, Universitas Kristen Satya Wacana

E-mail: endang.saputra966@gmail.com

\begin{abstract}
PT. XYZ, which is engaged in the manufacture of furniture and furniture components, was established in 2006. PT XYZ in carrying out its production uses production machines that are integrated with Information Systems. In every business process carried out by PT. XYZ requires IS/IT that supports every activity it carries out. PT XYZ uses production machines that are quite old. Conditions that occur at PT. XYZ can be explained in more detail using a risk management approach. The purpose of risk management is to manage existing risks based on the ISO 31000 standard so that the company gets optimal results.
\end{abstract}

Keywords: risk management, enterprise, ISO 31000, information systems, information technology

\section{Pendahuluan}

Perusahaan PT. XYZ yang bergerak di bidang pembuatan furniture dan komponen furniture berdiri pada tahun 2006. PT XYZ dalam menjalankan produksinya menggunakan mesin-mesin produksi yang terintegrasi dengan Sistem Informasi. Dalam setiap proses bisnis yang dilakukan oleh PT. XYZ membutuhkan SI/TI yang mendukung setiap aktivitas yang dijalankan. PT XYZ menggunakan mesin-mesin produksi dengan umur yang cukup tua. Hal diatas mengakibatkan menurunnya kualitas, Yang pada akhirnya menurunkan jumlah penjualan karena kalah bersaing dengan kompetitor. Melihat kondisi mesin-mesin produksi yang sudah cukup tua, akan mempengaruhi proses produksi pada PT. XYZ sehingga akan menyebabkan adanya kemungkinan terjadinya risiko yang dapat berdampak negatif bagi perusahaan. Dikarenakan semakin besar industri dan target pasarnya, maka akan semakin besar pula kemungkinan risikorisiko yang dapat terjadi. Hal itu akan mempengaruhi bagaimana sistem penjualan dan promosi yang dilakukan karena akan menghambat jumlah produksi barang yang akan dijual dan dipasarkan menggunakan sistem informasi penjualan. Sehingga akan menimbulkan berbagai risiko yang akan berdampak bagi perusahaan.

Oleh karena itu, maka yang menjadi tantangan dalam proses produksi di PT. XYZ saat ini adalah bagaimana mengurangi dampak risiko dari penggunaan mesin produksi untuk memaksimalkan proses produksi. Manajemen risko merupakan salah satu komponen penting dalam menjalankan bisnis perusahaan, karena semakin berkembangnya perusahaan secara global akan mengakibatkan meningkatnya tingkat risiko yang dihadapi oleh PT. XYZ. Tujuan dengan adanya implementasi manajemen risiko adalah melindungi perusahaan dari kerugian yang mungkin timbul.

Pilihan aktivitas produksi dalam pelaksanaannya dapat memiiki resiko yang akan mengganggu bahkan melumpukan aktivitas kinerja didalam nya. Resiko ini adalah termasuk resiko yang dapat muncul didalam pengunaan sistem informasi, dimana bisa berupa salah satu sistem informasi tidak dapat berjalan secara optimal sehingga berpengaruh terhadap proses produksi. Untuk peningkatan penjualan secara global dan memasarkan hasil produksi, PT XYZ menggunakan website sebagai sarana penjualan dan 
promosi. Salah satu aspek yang menjadi bagian penting dalam sistem informasi dan pengembangannya adalah aspek keamanan dan manajemen risiko. Seiring dengan berkembangnya sistem informasi pada saat ini beberapa hal penting yang menjadi faktor penentu agar sistem yang berjalan dapat befungsi dengan baik dan benar, karena selain efek positif yang muncul akibat berkembangnya sistem informasi maka permasalahan keamanan sistem informasi dan pengelolaan sumber daya teknologi informasi juga dapat terjadi.

PT. XYZ dapat melakukan pencegahan, penundaan, pengalihan dan penanganan serta perbaikan atau mitigasi terhadap kemungkinan-kemungkinan resiko yang terjadi. Karena dengan melakukan analisis risiko dapat membantu pengaturan risiko SI/TI, membantu perkembangan proses bisnis dan memberikan keuntungan, dan dapat memanajemen sumber daya perusahaan yang efektif. Dengan kata lain, analisis manajemen risiko adalah kegiatan yang dilakukan pada tingkat pimpinan perusahaan, yaitu berupa kegiatan pengamatan, identifikasi, klasifikasi dan analisa sistematis atas kerugian yang mungkin saja dapat dihadapi akibat suatu risiko serta cara pengendalian yang paling tepat untuk menangani kerugian yang dihubungkan dengan tingkat keuntungan yang akan dicapai oleh perusahaan. Kondisi yang terjadi pada PT. XYZ dapat dijelaskan dengan lebih detail menggunakan pendekatan manajemen resiko. [6] Manajemen resiko merupakan salah satu metode untuk mengetahui penyebab menurunnya kualitas produk penjualan perusahaan lewat identifikasi resiko, analisa resiko dan evaluasi resiko,yang ditentukan berdasarkan level tiap-tiap resiko yang telah terjadi dan kemungkinan-kemungkinan lainnya.

ISO 31000 merupakan pedoman standar, instruksi, dan tuntutan bagi sebuah organisasi atau perusahaan untuk membangun sebuah pondasi dan kerangka kerja bagi suatu program manajemen risiko. Pondasi tersebut meliputi aturan, tujuan, dan komitmen untuk membangun suatu program manajemen risiko yang komprehensif. Kerangka kerja meliputi perencanaan, akuntabilitas dari para pegawai, proses dan aktivitas yang digunakan untuk mengelola risiko dalam kinerja PT. XYZ. Tujuan dari standarisasi ini adalah untuk menyediakan prinsip-prinsip dan acuan dari program analisis manajemen risiko kepada perusahaan. Tujuan dari manajemen resiko adalah mengelola resiko-resiko yang ada berlandaskan standar dari ISO 31000 sehingga perusahaan mendapatkan hasil yang optimal. Berangkat dari permasalahan di atas perlu dilakukan suatu analisis manajemen resiko menggunakan standar dari ISO 31000 yang diharapkan dapat membantu PT.XYZ dalam pengambilan keputusan dan menjalankan proses bisnis yang berkaitan dengan penjualan.

\section{Tinjauan Literatur}

Semua resiko mewakili aktivitas-aktivitas yang tidak sah atau di luar dari yang diperbolehkan perusahaan. Aktivitas-aktivitas tersebut adalah pengungkapan dan pencurian informasi, penggunaan secara tidak sah, pengrusakan dan penolakan dan modifikasi yang tidak dibenarkan. [4] Manajemen resiko adalah suatu proses terstruktur dan sistematis dalam mengidentifikasi, mengukur, memetakan, mengembangkan alternatif penanganan risiko, dan dalam memonitor dan mengendalikan implementasi penanganan risiko dengan mengunakan metodelogi ISO 31000. [6] The International Organization for Standardization (ISO) 31000: 2009 Risk Management-Principles and Guidelines merupakan sebuah standar internasional yang disusun dengan tujuan 
memberikan prinsip dan panduan generik untuk penerapan manajemen resiko. Standar internasional yang diterbitkan pada 13 November 2009 ini dapat digunakan oleh segala jenis organisasi dalam menghadapi berbagai risiko yang melekat pada aktivitas mereka. Walau ISO 31000: 2009 menyediakan panduan generik, standar ini tidak ditujukan untuk menyeragamkan manajemen risiko lintas organisasi, tetapi ditujukan untuk memberikan standar pendukung penerapan manajemen risiko dalam usaha memberikan jaminan terhadap pencapaian sasaran organisasi. ISO 31000: 2009 menyediakan prinsip, kerangka kerja, dan proses manajemen risiko yang dapat digunakan sebagai arsitektur manajemen risiko dalam usaha menjamin penerapan manajemen risiko yang efektif.[5]

Menurut Stonebumer, Goguen, \& Feringa (2002) likelihood merupakan potensi kerentanan yang dapat dilakukan oleh sumber ancaman tertentu. Tingkat kemungkinan digambarkan sebagai tiga tingkatan dan ditabulasikan pada tabel 1 yang mendefinisikan tingkatan rendah, sedang, dan tinggi pada level likelihood, tujuannya untuk menentukan penilaian dalam tingkatan resiko yang terjadi dalam organisasi .[7]

Menurut Stonebumer, Goguen, \& Feringa (2002) dampak nyata dapat diukur secara kuantitatif dalam pendapatan yang hilang, biaya untuk memperbaiki sistem, atau tingkat upaya yang diperlukan untuk memperbaiki masalah yang disebabkan oleh tindakan ancaman. Dampak lain misalnya hilangnya kepercayaan publik, hilangnya kredibilitas, kemudian dijelaskan dalam hal tinggi, sedang, dan berdampak rendah. Karena sifat umum dari diskusi ini, panduan ini menunjukkan dan hanya menggambarkan kategori kualitatif dampak tinggi, sedang, dan rendah. Untuk pendefinisian masing- masing tingkatan dijelaskan pada tabel 2 .

Menurut Stonebumer, Goguen, \& Feringa (2002) matriks level risiko merupakan penentuan akhir nilai resiko yang diturunkan dengan mengalikan nilai likehood dengan nilai dampak dari setiap ancaman. Matriks yang digunakan berikut merupakan matriks $3 \times 3$ dengan rincian likelihood (tinggi, sedang, dan rendah) serta dampak ancaman (tinggi, sedang, dan rendah). Pada penentuan level resiko ini mungkin subjektif. Sehingga diperlukan alasan pembenaran yang dapat dijelaskan dalam setiap nilai likelihood dan magnitude of impact. [7]

Pada tahun 2017 dijelaskan oleh Susilo dan Kaho dalam buku manajemen resiko berbasis ISO 31000 untuk industri non perbankan, bahwa terdapat beberapa pilihan dalam perlakuan risiko diantaranya:

- Risk avoidance, digunakan untuk menghindari resiko dengan menghilangkan penyebab dan atau konsekuensi resiko. Misalnya, mematikan beberapa fungsi sistem atau keseluruhan sistem saat risiko teridentifikasi.

- Risk reduction, digunakan dengan mengurangi kemungkinan atau dampak. Misalnya pendidikan dan pelatihan bagi tenaga kerja untuk menghadapi resiko yang terjadi, perlindungan terhadap personil serta properti yang ada.

- Risk acceptance, dapat menerima resiko yang berarti sama dengan menanggung seluruh tanggung jawab atas resiko yang terjadi. Misalnya tidak menggunakan mengasuransikan server terhadap resiko kerusakan dan akan bersedia menanggung kerugian jika resiko kerusakan terhadap servernya.

- Risk sharing, digunakan untuk mentransfer resiko dengan mengunakan opsi lain untuk mengurangi dampak seperti membeli asuransi. [8] 


\section{Metode Penelitian}

Metode yang digunakan dalam penelitian ini merupakan metode deskriptif kualitatif. Penelitian kualitatif menggunakan teknik analisis yang bersifat induktif berdasarkan dengan fakta-fakta yang ada dilapangan, yang kemudian disusun menjadi hipotesis atau teori. Proses pencarian data mengunakan beberapa metode, diantaranya: Dengan melakukan tanya jawab kepada narasumber untuk mendapatkan data yang dibutuhkan oleh penulis. Suatu aktivitas dengan turun langsung ke lapangan untuk melengkapi datadata yang di perlukan.

Penulis mengunakan framework standar dari ISO 31000 yang bertujuan mengetahui manajemen resiko dengan tahapan proses identifikasi resiko, analisa resiko, dan evaluasi resiko,berdasarkan level tiap-tiap resiko yang sudah terjadi dan kemungkinankemungkinan lain pada suatu PT.XYZ sesuai dengan standar ISO 31000. Metodologi ini akan membantu organisasi dalam menentukan level dan kemungkinan resiko, meminimalisir resiko dan memberikan perlakuan terhadap resiko yang terjadi. Metodologi yang dilakukan penulis dalam mengumpulkan data adalah dengan melakukan wawancara, observasi dalam menentukan permasalahan kemungkinan resiko berdasarkan level-level resiko. Tahapan identifikasi kemungkinan resiko mengetahui masalah yang ada pada perusahaan dan memberikan perlakuan terhadap setiap resiko.

\section{Hasil dan Pembahasan}

Proses ini mencoba untuk mengidentifikasi kemungkinan resiko yang ada dan hasil dari 13 kemungkinan resiko-resiko yang ada tersebut menyebabkan kerugian finansial bagi organisasi. Untuk menentukan kemungkinan resiko tersebut sudah ditentukan melalui diskusi dengan pihak organisasi dan melihat resiko seperti apa yang akan dialami oleh perusahaan kedepanya. Detail dari identifikasi dampak risiko ini terdapat pada Tabel 1.

Tabel 1. Tabel Identifikasi Kemungkinan Resiko

\begin{tabular}{|c|l|}
\hline ID & \multicolumn{1}{|c|}{ Kemungkinan Resiko } \\
\hline KR1 & Kebocoran data atau informasi internal perusahaan \\
\hline KR2 & Hacking terhadap jaringan \\
\hline KR3 & Kehilangan koneksi internet \\
\hline KR4 & Server down \\
\hline KR5 & Maintenance tidak dilakukan secara berkala \\
\hline KR6 & Kesalahan jumlah pesanan yang diinput \\
\hline KR7 & Kesalahan jumlah pembayaran \\
\hline KR8 & Kelalaian dalam memasukan data \\
\hline KR9 & Listrik Padam \\
\hline KR10 & Monitoring jaringan LAN jika trouble \\
\hline KR11 & Serangan virus \\
\hline KR12 & Data Corrup \\
\hline KR13 & Kerusakan Hardware \\
\hline
\end{tabular}

Tahapan identifikasi kemungkinan resiko dan dampak proses ini mencoba untuk mengidentifikasi kemungkinan resiko seperti apa yang akan dialami oleh organisasi dan kemungkinan- kemungkinan dampak yang diterima oleh organisasi. detail dari 
identifikasi resiko terdapat pada Tabel 2.

Tabel 2. Identifikasi Dampak pada Kemungkinan Resiko

\begin{tabular}{|c|c|c|}
\hline ID & Kemungkinan Resiko & Dampak \\
\hline KR1 & $\begin{array}{l}\text { Kebocoran data atau informasi internal } \\
\text { perusahaan }\end{array}$ & $\begin{array}{l}\text { - Kerugian secara finansial/informasi berkaitan } \\
\text { dengan kerahasiaan perusahaan. }\end{array}$ \\
\hline KR2 & Hacking terhadap jaringan & $\begin{array}{l}\text { - Pencurian data-data penting perusahaan. } \\
\text { - Penyalahgunaan sumber daya pada jaringan. }\end{array}$ \\
\hline KR3 & Kehilangan koneksi internet & $\begin{array}{l}\text { - Gagal melakukan akses internet ke website } \\
\text { produk }\end{array}$ \\
\hline KR4 & Server down & $\begin{array}{l}\text { - Sulit/gagal melakukan akses ke database } \\
\text { utama. }\end{array}$ \\
\hline KR5 & $\begin{array}{l}\text { Maintenance tidak dilakukan secara } \\
\text { berkala }\end{array}$ & $\begin{array}{l}\text { - Mengganggu aktifitas pada system database } \\
\text { utama. }\end{array}$ \\
\hline KR6 & Kesalahan jumlah pesanan yang diinput & - Kerugian secara finansial \\
\hline KR7 & Kesalahan jumlah pembayaran & - Kerugian secara finansial \\
\hline KR8 & Kelalaian dalam memasukan data & - Kerugian secara finansial \\
\hline KR9 & Listrik padam & - Aktifitas perusahaan tidak dapat berjalan. \\
\hline KR10 & Monitoring jaringan LAN jika trouble & $\begin{array}{l}\text { - Bisa menyebab kan kerugian finansial akibat } \\
\text { terganggunya aktifitas karyawan dalam } \\
\text { bekerja ketika terjadi trouble pada jaringan }\end{array}$ \\
\hline KR11 & Serangan virus & $\begin{array}{l}\text { - Bisa menyebabkan kerugian terhadap } \\
\text { perusahaan } \\
\text { - Karna IT di setiap perusahaan membutuhkan } \\
\text { waktu yang relative lama untuk memperbaiki } \\
\text { komputer / PC yang telah terinfeksi virus } \\
\text { komputer. }\end{array}$ \\
\hline KR12 & Data Corrup & $\begin{array}{l}\text { - Data kepegawaianrusak dan tidak dapat } \\
\text { diakses. } \\
\text { - Terjadi masalah terkait dengan presensi } \\
\text { kehadiran, lembur, dan gaji dari karyawan. }\end{array}$ \\
\hline KR13 & Kerusakan Mesin Produksi & $\begin{array}{l}\text { - Gagal produksi } \\
\text { - Kerugian finansial }\end{array}$ \\
\hline
\end{tabular}

Resiko kerusakan mesin produksi dapat mempengaruhi proses produksi dimana akan berdampak pada kegagalan produksi dan kerugian finansial yang berhubungan dengan data pada sistem produksi yang tidak sesuai dengan perencanaan pada awal produksi.

Proses ini untuk mengidentifikasi kemungkinan resiko, level resiko, dampak resiko,serta usulan perlakuan terhadap resiko. Dampak Seperti apa yang akan dialami oleh perusahaan jika kemungkinan- kemungkinan risiko yang sudah diidentifikasi bisa mengakibatkan kerugian finansial, penulis memfokuskan level Resiko guna untuk menentukan hal yang paling diwaspadai dan berdampak kerugian secara finansial berdasarkan level (high,medium,low) hasil penentuan dari indetifikasi kemungkinan resiko ini penulis sebelumnya telah berdiskusi kepada pihak organisasi untuk menetapkan kemungkinan resiko yang mengakibatkan kerugian finansial yang akan dialami oleh organisasi ketika hal itu terjadi dikemudian hari, dan langkah selanjutnya penulis memberikan usulan perlakuan terhadap resiko yang ada. Detail dari identifikasi dampak risiko terdapat pada Tabel 3. 


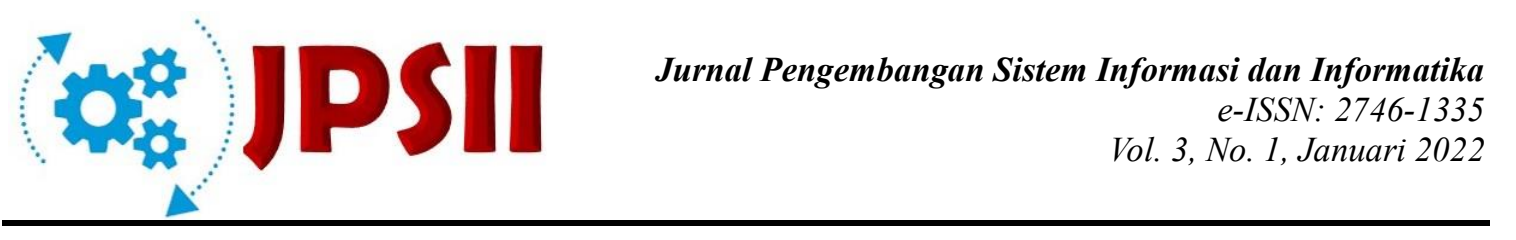

Tabel 3. Identifikasi Resiko Dan Usulan Perlakuan Terhadap Resiko

\begin{tabular}{|c|c|c|c|c|}
\hline ID & $\begin{array}{l}\text { Kemungkinan } \\
\text { Resiko }\end{array}$ & $\begin{array}{l}\text { Level } \\
\text { Resiko }\end{array}$ & Dampak Resiko & Usulan Perlakuan terhadap Resiko \\
\hline KR 9 & $\begin{array}{l}\text { Listrik } \\
\text { Padam }\end{array}$ & High & $\begin{array}{l}\text { - Terkendala nya } \\
\text { pekerjaan karna } \\
\text { Listrik berperan } \\
\text { penting dalam }\end{array}$ & $\begin{array}{l}\text { - Penyediaan generator set dan UPS } \\
\text { (Uninterruptible Power Supply)dengan } \\
\text { daya yang disesuaikan terhadap } \\
\text { kebutuhan seluruh perusahaan. } \\
\text { - Menggunakan } 2 \text { (dua) atau lebih sumber } \\
\text { listrik dari gardu listrik yang dibedakan. }\end{array}$ \\
\hline KR12 & Data corrupt & High & $\begin{array}{l}\text { - terjadinya kerusakan } \\
\text { terhadap perangkat } \\
\text { keras mengakibatkan } \\
\text { kerugian bagi } \\
\text { perusahaan }\end{array}$ & $\begin{array}{l}\text { - Selalu melakukan backup data } \\
\text { - Melakukan permbersihan pada hardware } \\
\text { PC agar PC terawatt } \\
\text { - Mencegah munculnya virus/malware } \\
\text { yang dapat menyebabkan data corrupt } \\
\text { dengan scan antivirus secara berkala. }\end{array}$ \\
\hline KR2 & $\begin{array}{l}\text { Hacking } \\
\text { terhadap } \\
\text { jaringan }\end{array}$ & Medium & $\begin{array}{l}\text { - pencurian dan } \\
\text { penyalahan gunaan } \\
\text { terhadap data } \\
\text { perusahaan oleh } \\
\text { orang yang tidak } \\
\text { bertangung jawab }\end{array}$ & $\begin{array}{l}\text { - Melakukan perlindungan data yang } \\
\text { paling rentan diretas harus diutamakan } \\
\text { penanganannya bila perlu menyewa } \\
\text { konsultan cybersecurity untuk melakukan } \\
\text { audit demi melindungi data yang ada. }\end{array}$ \\
\hline KR8 & $\begin{array}{l}\text { Kelalaian } \\
\text { dalam } \\
\text { memasukan } \\
\text { data }\end{array}$ & Medium & $\begin{array}{l}\text { - Menyebabkan } \\
\text { kerugian financial }\end{array}$ & $\begin{array}{l}\text { - Mengoreksi kembali data yang salah } \\
\text { dalam pengimputan berguna mencegah } \\
\text { terjadinya kesalahan dalam memasukan } \\
\text { data }\end{array}$ \\
\hline KR 3 & $\begin{array}{l}\text { Kehilangan } \\
\text { koneksi } \\
\text { internet }\end{array}$ & Medium & $\begin{array}{l}\text { - menyebabkan } \\
\text { terjadinya trouble } \\
\text { yang terlalu lama } \\
\text { dalam proses } \\
\text { produksi }\end{array}$ & $\begin{array}{l}\text { - Segera melaporkan kepada bagian } \\
\text { jaringan jika dirasa koneksi jaringan } \\
\text { mengalami masalah. }\end{array}$ \\
\hline KR 5 & $\begin{array}{l}\text { Proses } \\
\text { maintenance }\end{array}$ & Medium & $\begin{array}{l}\text { - ketika tidak } \\
\text { dilakukan } \\
\text { maintanancesewaktu- } \\
\text { waktu bisa terjadi } \\
\text { kerusakan data atau } \\
\text { data hilang }\end{array}$ & $\begin{array}{l}\text { - Menyusun jadwal maintenance program } \\
\text { secara berkala. Maintenance sebaiknya } \\
\text { dijadwalkan sebelum jam kerja dimulai. } \\
\text { - Memberikan pengumuman kepada bagian } \\
\text { maintanance sebelum meperbaiki } \\
\text { kerusakan yang terjadi. } \\
\text { - Pengumuman diinformasikan secepatnya } \\
\text { setelah mengetahui adanya kerusakan. }\end{array}$ \\
\hline KR 4 & Server down & Medium & $\begin{array}{l}\text { - Menghambat } \\
\text { Pekerjaan }\end{array}$ & $\begin{array}{l}\text { - Melakukan pengecekan secara berkala } \\
\text { dalam } 1 \text { hari terhadap } d b \log \text {, temp } d b \\
\text { log, CPU usage, dan } R A M \text {. }\end{array}$ \\
\hline KR10 & $\begin{array}{l}\text { Monitoring } \\
\text { jaringan } \\
\text { LAN hanya } \\
\text { dilakukan } \\
\text { jika ada } \\
\text { masalah atau } \\
\text { trouble saja } \\
\text { (tidak ada } \\
\text { monitoring } \\
\text { yang } \\
\text { spesifik) }\end{array}$ & Medium & $\begin{array}{l}\text { - Terjadinya trouble } \\
\text { disaat pekerjaan bisa } \\
\text { menghambat proses } \\
\text { produksi pemesanan } \\
\text { barang } \\
\text { mengakibatkan } \\
\text { kerugian bagi } \\
\text { perusahaan }\end{array}$ & $\begin{array}{l}\text { - Harus dilakukannya monitoring ketika } \\
\text { terjadi masalah atau trouble bisa diatasi } \\
\text { sebelum masalah itu terjadi. }\end{array}$ \\
\hline KR11 & $\begin{array}{l}\text { Serangan } \\
\text { virus }\end{array}$ & Medium & $\begin{array}{l}\text { - perangkat keras akan } \\
\text { error }\end{array}$ & $\begin{array}{l}\text { - Update software antivirus berbayar untuk } \\
\text { melindungi data pada komputer/pc untuk } \\
\text { menghindari serangan virus komputer. }\end{array}$ \\
\hline
\end{tabular}




\begin{tabular}{|c|c|c|c|c|}
\hline KR 7 & $\begin{array}{l}\text { Kesalahan } \\
\text { input data } \\
\text { jumlah } \\
\text { pembayaran }\end{array}$ & Medium & $\begin{array}{l}\text { - mengakibat kan } \\
\text { terjadinya kekeliruan } \\
\text { terhadap } \\
\text { pengimputan data } \\
\text { berdampak kerugian } \\
\text { bagi perusahaan } \\
\end{array}$ & $\begin{array}{l}\text { - Melakukanpengecekan secara berkala } \\
\text { terhadap data yang salah dalam } \\
\text { pengimputan. }\end{array}$ \\
\hline $\begin{array}{c}\text { KR } \\
13\end{array}$ & $\begin{array}{l}\text { Kerusakan } \\
\text { hardware }\end{array}$ & Low & $\begin{array}{l}\text { - Terhambat nya proses } \\
\text { produksi dan } \\
\text { pekerjaan yang } \\
\text { berhubungan dengan } \\
\text { perangkat keras }\end{array}$ & $\begin{array}{l}\text { - Menjaga kebersihan dan penggunaan } \\
\text { hardware- hardware yang ada. Segera } \\
\text { melaporkan kepada bagian teknisi jika } \\
\text { ditemukan hardware yang bermasalah } \\
\text { agar bisa langsung ditanggulangi. }\end{array}$ \\
\hline KR 6 & $\begin{array}{l}\text { Kesalahan } \\
\text { jumlah } \\
\text { pesanan } \\
\text { yang diinput }\end{array}$ & Low & $\begin{array}{l}\text { - bisa berakibat tidak } \\
\text { valid nyadalam } \\
\text { proses output }\end{array}$ & $\begin{array}{l}\text { - Mengoreksi kembali data yang salah } \\
\text { dalam pengimputan untuk mencegah } \\
\text { terjadinya kesalahan dalam memasukan } \\
\text { data }\end{array}$ \\
\hline KR1 & $\begin{array}{l}\text { Kebocoran } \\
\text { data atau } \\
\text { informasi } \\
\text { internal } \\
\text { perusahaan }\end{array}$ & Low & $\begin{array}{l}\text { - Data bisa disalah } \\
\text { gunankan oleh pihak } \\
\text { yang tidakbertangung } \\
\text { jawab }\end{array}$ & $\begin{array}{l}\text { - Memasang password unik untuk akses } \\
\text { data penting dari bagian software } \\
\text { passwordbisa dibuat dengan kombinasi } \\
\text { huruf besar, huruf kecil, angka, dan tanda } \\
\text { baca dengan minimal karakter untuk } \\
\text { sebuah password adalah } 10 \text { karakter. }\end{array}$ \\
\hline
\end{tabular}

Setelah menyelesaikan tahap identifikasi, tahap selanjutnya adalah tahap analisis resiko. pada proses ini akan dilakukan penilaian terhadap kemungkinan-kemungkinan risiko yang sudah teridentifikasi. Penentuan nilai ini akan dilakukan berdasarkan kemungkinan (likelihood) dan dampak (impact) yang dapat dilihat pada Tabel 4 dan Tabel 5.

Bertujuan menetukan level, kriteria, dan uraian kejadian (1 tahun). Identifikasi yang dilakukan untuk mengetahui nilai level $(1,2,3,4,5)$ tiap resiko yang sering terjadi dalam kurun waktu 1 tahun.

Tabel 4. Penentuan Kriteria Likelihood

\begin{tabular}{|c|l|l|}
\hline Level & \multicolumn{1}{|c|}{ Kriteria } & \multicolumn{1}{c|}{ Uraian (1 tahun) } \\
\hline 1 & Jarang & $\begin{array}{l}\text { Mungkin terjadi hanya pada kondisi tidak normal; } \leq 3 \\
\text { kejadian }\end{array}$ \\
\hline 2 & Likelihood kecil & Mungkin terjadi pada beberapa waktu; 3 - 5 kejadian \\
\hline 3 & Likelihood sedang & Dapat terjadi pada beberapa waktu; 6 -10 kejadian \\
\hline 4 & Likelihood besar & $\begin{array}{l}\text { Akan mungkin terjadi pada banyak keadaan; 11 - 20 } \\
\text { kejadian }\end{array}$ \\
\hline 5 & Hampir pasti & Dapat terjadi pada banyak keadaan; $\geq 20$ kejadian \\
\hline
\end{tabular}

Bertujuan menetukan level, kriteria, dan uraian kejadian (1 tahun). Identifikasi yang dilakukan untuk mengetahuin nilai level $(1,2,3,4,5)$ tiap resiko yang sering terjadi dalam kurun waktu 1 tahun.

Tabel 5. Penentuan Kriteria Impact

\begin{tabular}{|c|l|l|}
\hline Level & \multicolumn{1}{|c|}{ Kriteria } & \multicolumn{1}{|c|}{ Uraian(1 tahun) } \\
\hline 1 & $\begin{array}{l}\text { Tidak } \\
\text { signifikan }\end{array}$ & Dampak mungkin diabaikan dengan aman. \\
\hline 2 & Impact kecil & $\begin{array}{l}\text { Dampak kecil dan dapat diatasi dengan prosedur } \\
\text { sederhana }\end{array}$ \\
\hline
\end{tabular}




\begin{tabular}{|c|l|l|}
\hline 3 & Impact sedang & $\begin{array}{l}\text { Dampak tergolong besar, namun dapat dikelola } \\
\text { dengan menggunakan prosedur }\end{array}$ \\
\hline 4 & Impact besar & $\begin{array}{l}\text { Dampak besar, berpotensi pada financial dan } \\
\text { terhambatnya kinerja organisasi }\end{array}$ \\
\hline 5 & $\begin{array}{l}\text { Impact } \\
\text { emergency }\end{array}$ & $\begin{array}{l}\text { Dampak ekstrim, berpotensi pada large financial } \\
\text { dan terhentinya kinerja organisasi, serta dampak } \\
\text { pada reputasi organisasi }\end{array}$ \\
\hline
\end{tabular}

Setelah melakukan penentuan nilai pada kemungkinan (likelihood) di Tabel 4 dan pada dampak (imfact) di Tabel 5, selanjutnya adalah memulai penilaian terhadap kemungkinan-kemungkinan resiko yang berada di sekitar dari aset-aset yang terkait dengan sistem informasi perusahaan yang sudah teridentifikasi sebelumnya. Detail dari penilaian kemungkinan- kemungkinan risiko dapat dilihat pada Tabel 6 .

Setelah menyelesaikan tahap analisa resiko selanjutnya proses penilaian likelihood dan impact tujuanya untuk memberikan nilai pada Setiap level kemungkinan resiko yang diberikan . Dapat dilihat pada Tabel 6 berikut :

\begin{tabular}{|c|c|c|c|}
\hline ID & Kemungkinan Resiko & Likelihood & Imfact \\
\hline KR 1 & Kebocoran data atau informasi internal perusahaan & 2 & 3 \\
\hline KR 2 & Hacking terhadap jaringan & 3 & 2 \\
\hline KR 3 & Kehilangan koneksi internet & 2 & 3 \\
\hline KR 4 & Server down & 3 & 3 \\
\hline KR 5 & Proses maintenance & 2 & 2 \\
\hline KR 6 & Kesalahan jumlah pesanan yang diinput & 1 & 3 \\
\hline KR 7 & Kesalahan jumlah pembayaran & 2 & 3 \\
\hline KR 8 & Kelalaian dalam memasukan data & 1 & 2 \\
\hline KR 9 & Listrik padam & 1 & 4 \\
\hline KR 10 & $\begin{array}{l}\text { Monitoring jaringan LAN hanya dilakukan jika ada } \\
\text { masalah atau trouble saja (tidak ada monitoring yang } \\
\text { spesifik) }\end{array}$ & 2 & 3 \\
\hline KR 11 & Serangan virus & 1 & 1 \\
\hline KR 12 & Data Corrup & 1 & 2 \\
\hline KR 13 & Kerusakan Hardware & 1 & 2 \\
\hline
\end{tabular}

Pada tahapan evaluasi risiko ini, kemungkinan- kemungkinan resiko yang sudah diidentifikasi serta dianalisis sebelumnya akan dimasukan ke dalam sebuah matrik evaluasi risiko berdasarkan kemungkinan (likelihood) dan dampak (imfact). Pembentukan matrik evaluasi resiko didapat berdasarkan dari parameter evaluasi risiko yang sudah ditentukan. Secara lebih detail, parameter evaluasi risiko dapat dilihat pada Tabel 6, penulis ingin menentukan nilai parameter pada keseluruh indentifikasi melalui tabel matriks agar bisa menunjukan level high,medium,low berserta dampak apa yang diterima oleh perusahaan ketika terjadinya suatu masalah pada setiap resiko yang sudah diindetifikasi, sementara untuk matrik evaluasi resiko berdasarkan kemungkinan (likelihood) dan dampak (imfact) dapat dilihat pada gambar 1. 

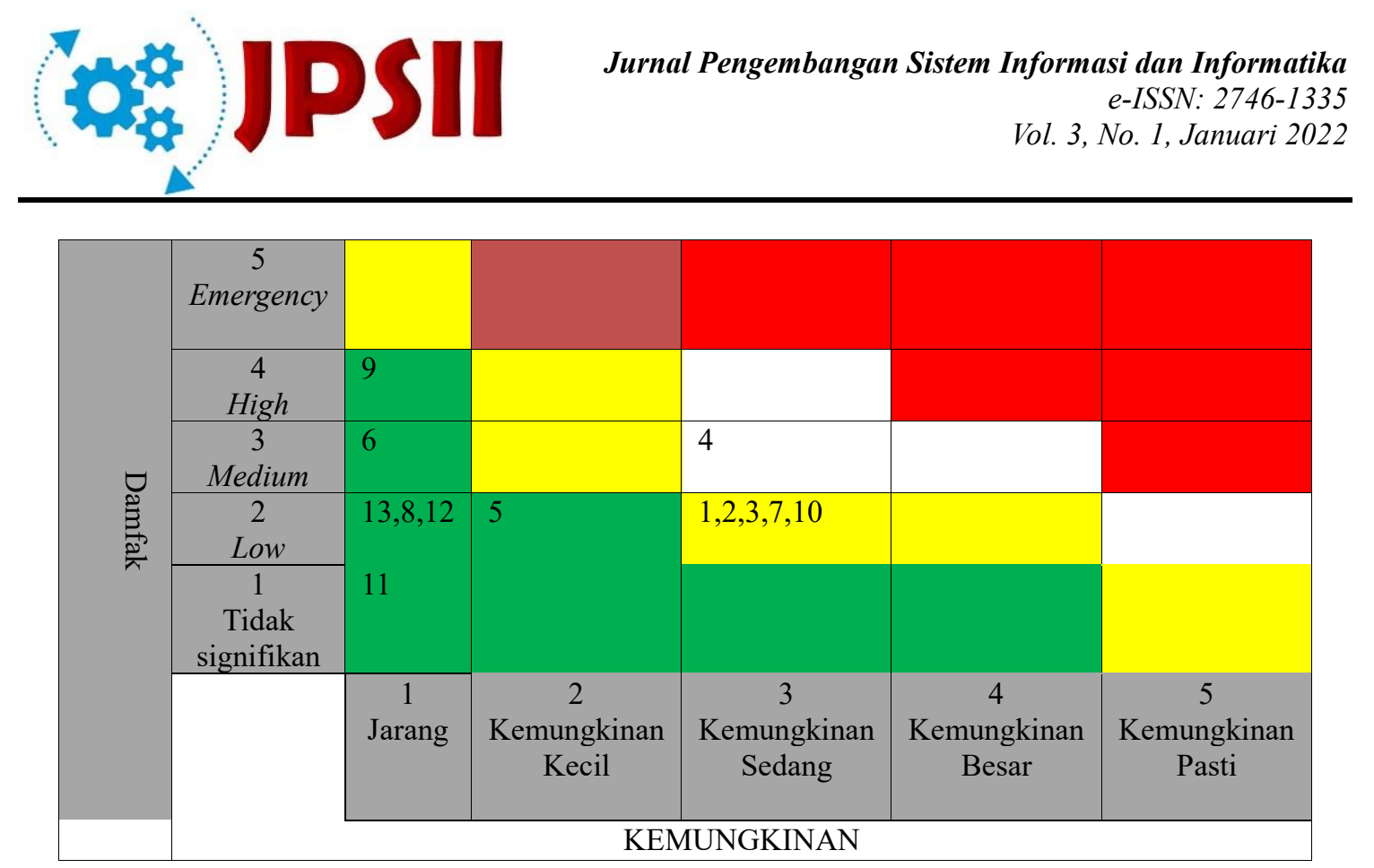

\section{Gambar 1. Matriks Evaluasi Resiko}

Gambar 1. merupakan matrik yang telah diisi menggunakan nilai yang telah sesuai dengan nilai yang diberikan pada analisa sebelumnya dimana beberapa resiko yang ditimbulkan seperti kerusakan mesin produksi dan permasalahan pada sistem informasi maupun teknologi informasi yang dimiliki perusahaan dapat menyebabkan kerugiankerugian bagi perusahaan XYZ, dapat dilihat pada (Tabel 4 dan Tabel 5) sesuai dengan tingkatan resiko yang terdapat pada Gambar 1. Seperti pada Gambar 1, maka antisipasi yang dapat dilakukan oleh PT. XYZ adalah dengan selalu melakukan pemeliharaan terhadap mesin produksi guna meminimalisir resiko kerusakan mesin produksi yang dapat

\section{Kesimpulan}

Berdasarkan hasil analisis pada sistem informasi penjualanPT.XYZ terdapat beberapa poin yang menjadi simpulan, diantaranya: Analisis terhadap sistem informasi penjualan menggunakan ISO 31000 dilakukan dalam beberapa tahapan antara lain melakukan wawancara dan konsultasi, kemudian menetapkan indentifikasi resiko, analisa resiko, evaluasi resiko dan usulan terhadap perlakuan tiap-tiap level resiko yang ada. Setelah dilakukan serangkaian proses manajemen resiko berdasarkan ISO 31000, maka didapatkan hasil tingkatan resiko yang memiliki nilai kemungkinan dan nilai dampak yang terjadi pada sistem penjualan, baik data perangkat lunak, perangkat keras, sumber daya manusia dan prosedur yang terkait pada sistem sistem penjualan yang dinilai dapat mengganggu proses bisnis PT.XYZ. Sehingga diperlukan peninjauan kembali oleh pihak perusahaan dan penerapan perlakuan resiko yang telah dianalisis. Berdasarkan hasil analisis, didapatkan bahwa hampir setiap aset dan perangkat pendukung, membutuhkan aliran listrik dan dan koneksi internet yang baik, sehingga perangkat dapat berjalan dengan optimal dan dibutuhkan juga pembaruan sumber daya manusia atau pelatihan agar tidak mengganggu proses bisnis perusahaan. Perusahaan perlu melakukan pemeliharaan mesin produksi secara berkala guna meminimalisir resiko kerusakan mesin produksi.

\section{Referensi}

Amriani, Selvi. 2012. Analisa Risiko Teknologi Informasi Berbasis ISO 31000/31010 (Studi Kasus Lembaga Penelitian Perguruan Tinggi). Jurnal Sistem Informasi Volume 7, 


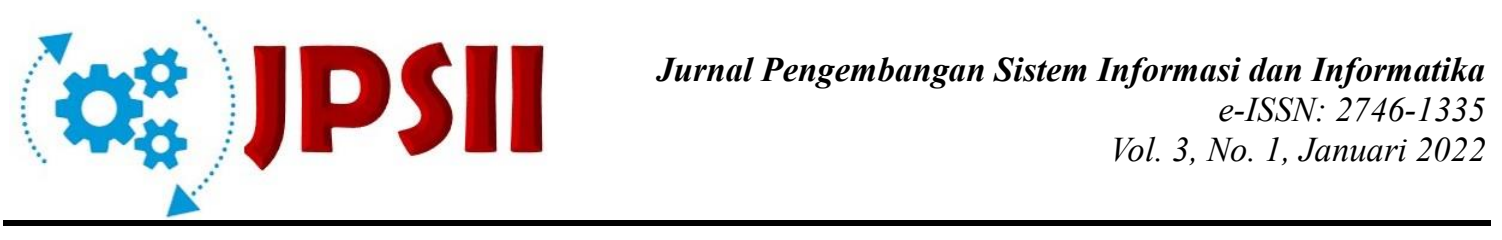

No. 2, September 2012.

Husein, Gilang M. \&Radiant Victor Imbar.2015. Analisis Manajemen Resiko

Teknologi Informasi Penerapan Pada Document Management System di PT. Jabar Telematika (JATEL).Jurnal Teknik Informatika dan Sistem Informasi, Vol 1 No.2. pp. 75 87.

M. J. Raymond and P. George.2011.Sistem Informasi Manajemen Edisi Kesembilan. Jakarta: PT.Index.

Megawati, Trivina A, Hanim Maria A, \& Anisah H.2014.Pengelolaan Risiko Aset Teknologi Informasi Pada PT. XYZ Tangerang Berdasarkan Kerangka Kerja Cobit 4.1.Open Access Journal of Information Systems (OAJIS)Vol. 2014.

Rilyani, Andi Novia, Yanuar Firdaus, \& Dawam Dwi J. 2015. Analisis Risiko Teknologi Informasi Berbasis Risk Management Menggunakan ISO 31000 (Studi Kasus i-Gracias Telkom University). Jurnal e-Proceeding of Enginering Vol: 2, No.2 Agustus 2015.

S. Leo J \& R. K. Victor.2010.Manajemen Risiko Berbasis ISO 31000 untuk Industri Non Perbankan. Jakarta: PPM.

Stonebumer, G., Goguen, A. \& Feringa, A., 2002. Risk Management Guide for Information Technology Gaithersburg.Amerika Serikat: National Systems.Institute of Standards and Technology.

Susilo, L. J. \& Kaho, V. R.2017. Manajemen Risiko berbasis ISO 31000 untuk Industri Non Perbankan. Jakarta Pusat: PPM.

Y. H. M. and R. Hidayat.2009.CMM Website Interaktif MCMS Joomla (CMS).Jakarta: PT. Elex Media Komputindo.

\section{Copyrights}

Copyright for this article is retained by the author(s), with first publication rights granted to the journal.

This is an open-access article distributed under the terms and conditions of the Creative Commons Attribution license (http://creativecommons.org/licenses/by/4.0/) 